\title{
EXPERIMENTAL RESULTS OF TURBO-AGGREGATE VIBROACOUSTIC DIAGNOSIS OBTAINED WITH VIBRO-EXPERT SYSTEM FOR ONE TURBO AGGREGATE IN LUKOIL REFINERY
}

\author{
Cornel Marin ${ }^{1}$, Ionel Rusa ${ }^{2}$ \\ 1,2 VALAHIA University of Târgoviște, FIMM, Str. Aleea Sinaia, No.13, Targoviste \\ marincor@yahoo.com, ionelrusa@gmail.com
}

\begin{abstract}
Proactive maintenance is a relatively new concept used today by the exploitation of manufacturing and energy production systems consisting of vibro acoustic monitoring of installations and equipment with professional equipment, such as Expret-Vibro and PROFISIGNAL software. These vibration level measurements are required for vibro acoustic diagnosis and for timely programming of repairs that are being challenged before accidental malfunctions occur. Electric steam turbines are used to produce electrical energy in refineries, which are particularly complex and are equipped with a turbine shaft located on several sliding or rolling bearings. Vibration sensors are mounted on bearing housings and are formed from one-axial, biaxial and three-axial accelerometers for absolute magnitudes (P-P and RMS speeds) or laser proximal sensors (relative and offset displacements). These sensors transmit the signals of data acquisition cards and amplifiers for data processing
\end{abstract}

Keywords: Vibration Diagnosis, Vibro-Expert System, Proactive Maintenance

\section{Introduction}

Measurement of the vibration level was performed on the TA4 Turbo Aggregate in the LUKOIL operating state at normal mode parameters. Diagnosis of the operating state is based on measurements of the absolute vibrations in the TA4 turbine units by means of one-axial accelerometers VIBRASENS 101.51-9 and measurements of the relative vibrations of the spindle (orbital) by means of some proximity sensors ROLS-W - produced by Monarch Instruments.

The four bearings on which the sensors are mounted are shown in Figure 1. The normal operating parameters of the LUKOIL TA4 torqueaggregate are:

- Power: $32 \mathrm{MW}$;

- Speed: $3000 \mathrm{rpm}$;

- Stator type: $11 \mathrm{kV}, 2100 \mathrm{~A}$,

- Tip Rotor: $532 \mathrm{~A}$

- Water flow: $150 \mathrm{mc} / \mathrm{h}$

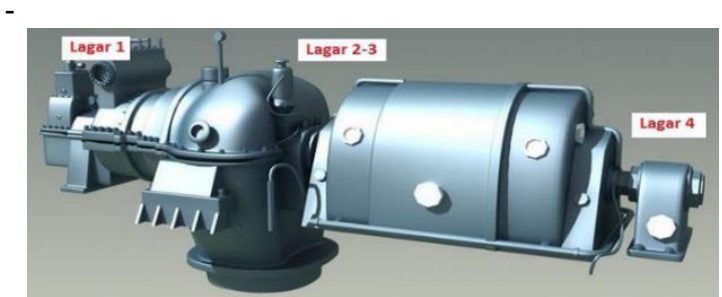

Figure 1: 3D Model virtual of Turbo Agregate TA4

\section{Expert Vibro Data Acquisition and Processing System}

The Expert Vibro Diagnostic System Integration Scheme and Modules in the April-May 2017measurements on the TA4 Turbo Aggregate in the normal operation of the LUKOIL frame is shown in Figure 2 and 3 includes the following equipment and modules:

- Expert Vibro Diagnostic System, PC Computer

- Speed sensors, accelerometers and laser proximity transducers, air gap sensors

- The TRAFO diagnosis module

- The way it diagnoses temperatures

- Process process acquisition process - PLC

- Module diagnosis Rotor parameters

\section{Technical Conditions of Measurement, Operating Regimes and Types of Measurements}

Technical conditions for vibration measurements and experimental data processing are in according with international standards: ISO 7919-1: 1996 [9]; ISO 7919-3: 1996 [10]; ISO 10816-1: 1995 [12] and ISO 10816-3: 2009 [13].

One-axial and three-axial accelerometers were used along the $\mathrm{X}, \mathrm{Y}, \mathrm{Z}$ directions as shown in the positioning scheme of the measuring points in Figure 
3 , in particular, the positioning of the sensors on the bearing 4in Figure 4, 5and 6, the two posts and the post of the bearing, according to the vertical directions - V, Horizontal - 0 and Axial - To the bearing and the post, respectively to the $\mathrm{X}, \mathrm{Y}$ and $\mathrm{Z}$ directions for the pillars. Vibration measurements were performed for the following operating modes:

a. At $3000 \mathrm{rpm}$ and $20 \mathrm{MW}$ power with 8 metal plates mounted on bearing 4 .

b. At $3000 \mathrm{rpm}$ and the power of $14 \mathrm{MW}$ with $8 / 7 / 6 / 5 / 4 / 3 / 1 / 0$ metal plates mounted on bearing 4
With the Expert Vibro Diagnostic System, global vibration values were monitored:

- Relative vibrations of the Turbo Aggregate shaft TA4 according to ISO 7919-3

- Absolute vibrations of turbine aggregate TA4 according to ISO 10816-3

- Amplitude of base - component 1x - $50 \mathrm{~Hz}, 2 \mathrm{x}$ $100 \mathrm{~Hz}, 3 \times 150 \mathrm{~Hz}$ recorded on Bearing 4 and its mount in vertical direction.

- Waveforms and Frequency Spectra for acceleration, velocity and displacement

- Orbite cams and vibrations absolute and relative etc.

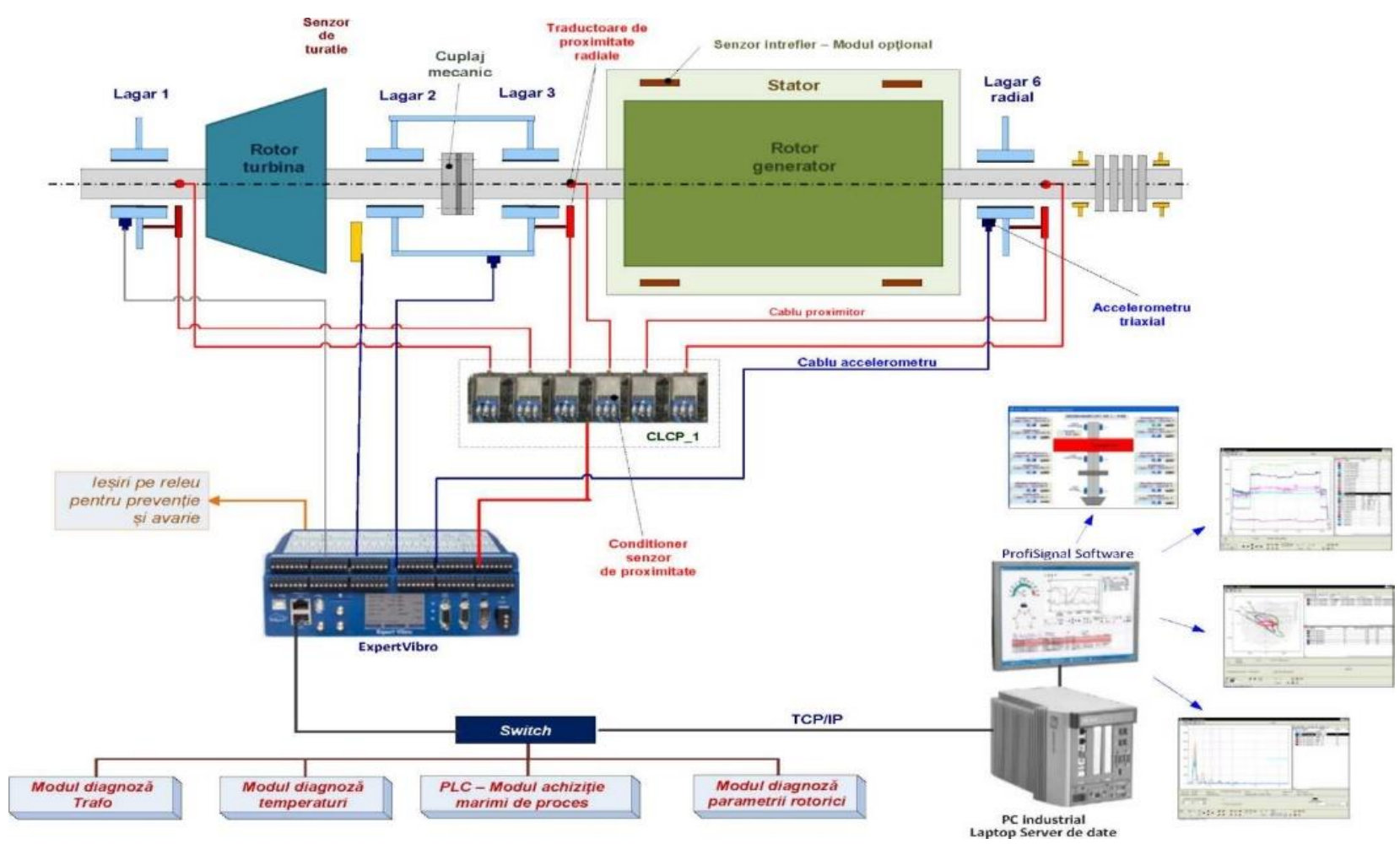

Figure 2: Expert Vibro diagnostic system integration block diagram

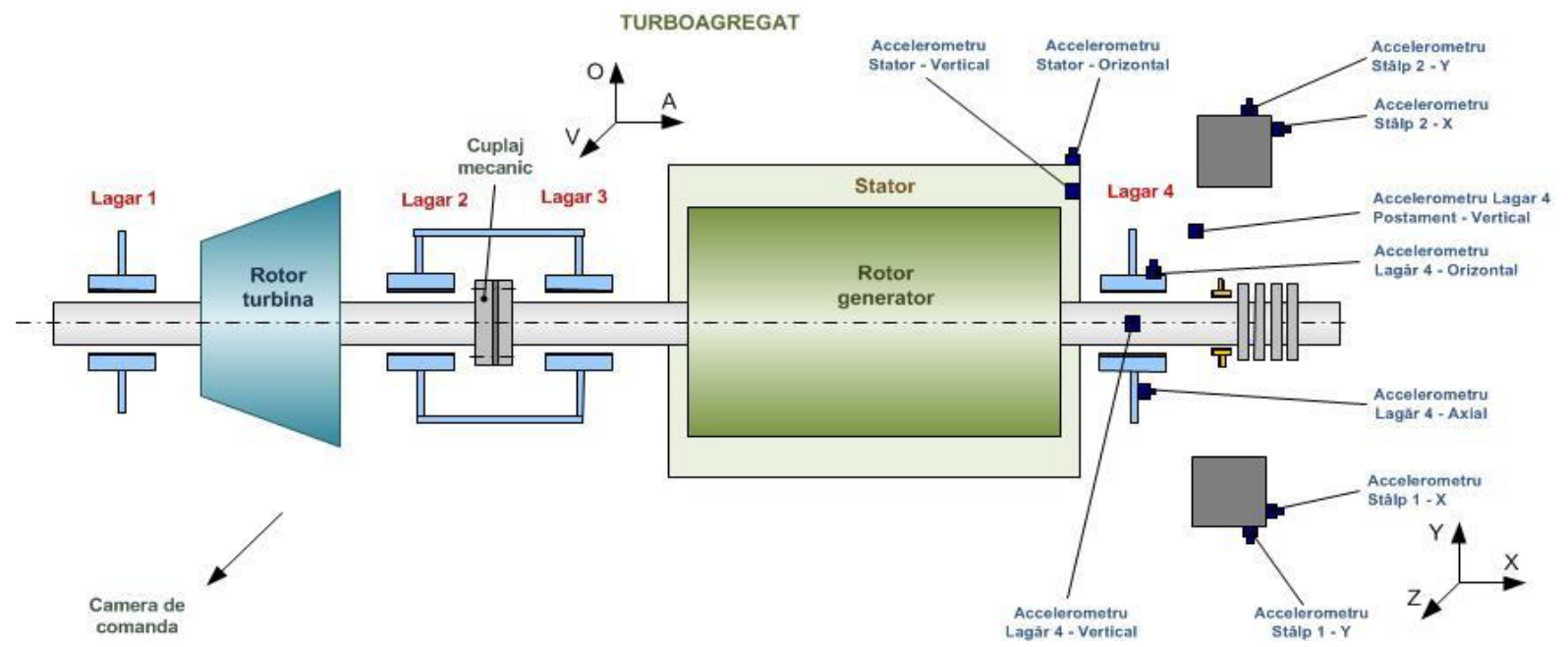

Figure 3: Location of vibration measurement points on bearing 4 (Axial, Vertical and Horizontal), pillars ( $X$ and $Y$ direction) and base (vertical) 


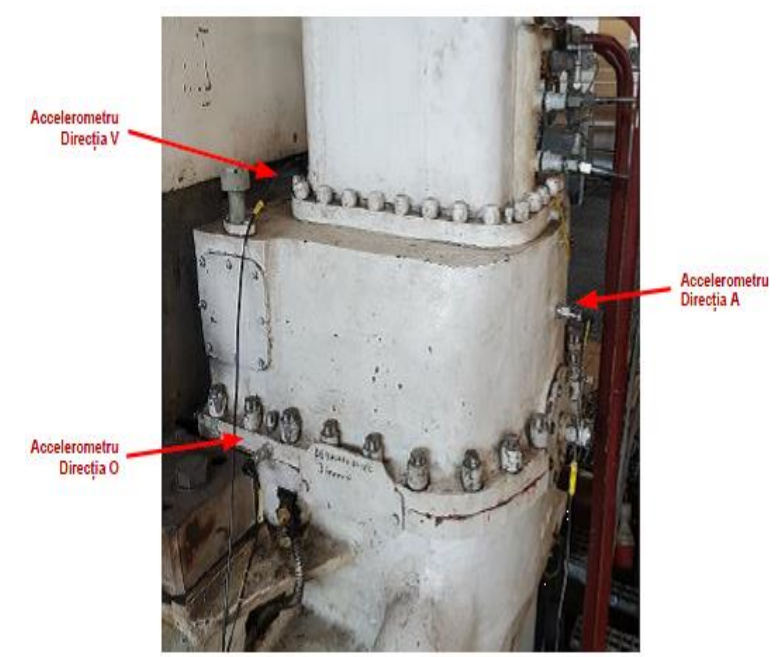

Figure 4: Mounting of accelerometers on bearing

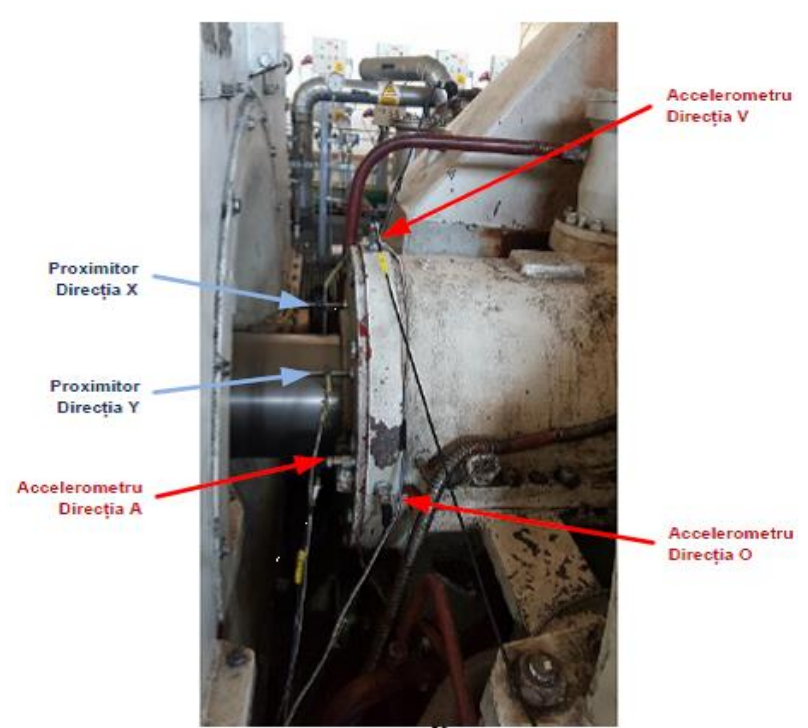

Figure 5: Mounting of accelerometers and proximity sensors on bearings 2-3

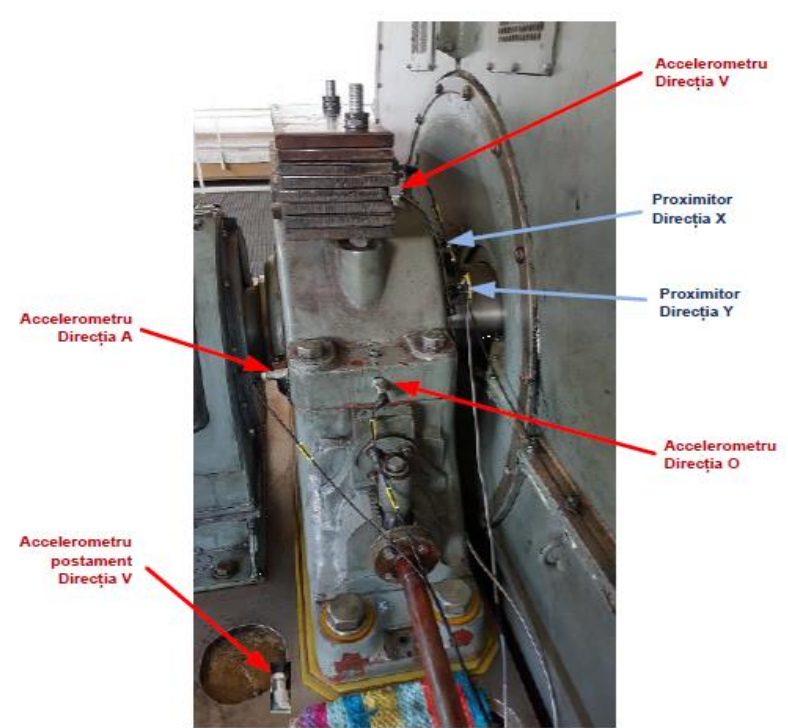

Figure 6: Mounting of accelerometers and proximity sensors on bearings 4 and basis 
Table 1.

\begin{tabular}{|c|c|c|c|c|}
\hline & & IS07919-3:1996 & \multicolumn{2}{|c|}{ ISO 10816-3:2009 } \\
\hline \multicolumn{2}{|c|}{ Machine } & $\begin{array}{c}\text { Turboagregate } \\
3000 \mathrm{rpm}, \mathrm{P}=32[\mathrm{MW}]\end{array}$ & \multicolumn{2}{|c|}{$\begin{array}{c}\text { Turboagregate } \\
3000 \mathrm{rpm}, \mathrm{P}=32[\mathrm{MW}]\end{array}$} \\
\hline \multicolumn{2}{|c|}{$\begin{array}{l}\text { Measurement } \\
\text { parameter }\end{array}$} & $\begin{array}{l}\text { Displacement } \\
\text { Pick- pick[ }[\mu \mathrm{m}]\end{array}$ & $\begin{array}{l}\text { Speed RMS } \\
{[\mathrm{mm} / \mathrm{s}]}\end{array}$ & 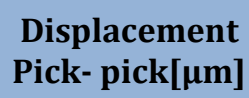 \\
\hline \multirow{4}{*}{$\begin{array}{l}\text { Performance } \\
\text { ratings }\end{array}$} & Good - A & under 85 & under 2,3 & under 29 \\
\hline & Usable - B & $85-160$ & $2,3-4,5$ & $29-57$ \\
\hline & $\begin{array}{c}\text { Admitted } \\
\text { under } \\
\text { supervision - C }\end{array}$ & $160-240$ & $4,5-7,1$ & $57-90$ \\
\hline & Not allowed - D & over 240 & over 7,1 & over 90 \\
\hline
\end{tabular}

ISO Standard 7919-3: 1996 and ISO 10816-3: 2009 establishes the performance ratings of the Turbo Aggregate when it is stable from the energy point of view, as shown in Table 1:

- Rating A - Good / Vibration rating of newly installed machines enters this area.

- Rating B - Usable / Machine vibrations within this area are normally considered acceptable for unrestricted operation in the long regime operation.

- Qualification C - Admitted under supervision / Machines where the vibrations within this area are normally considered unsatisfactory for continuous, long-term operation.

- Qualification D - Not allowed / Machines where vibrations within this area are considered to be severe enough to cause damage to the machine.

\section{Results Obtained Using Expert Vibro Data Acquisition, Measurement and Data Acquisition System}

Following the vibration measurements, high vibration amplitudes relative to the bearing 2-3 were measured, and on the bearing 4 the values of the relative vibration amplitudes are small. The vibration amplitudes have been recorded for both working modes, the machine's performance rating is usable - according to the Global Relative Vibration Level Bulletin No. 1. [7]

From the diagnosis of the relative vibrations of the intermediate bearings $2-3$ and the end bearing 4 , there results a slight loading of the bearing 2-3 which may lead to the de-shafting of the shafts in the vertical direction according to Figure A.9 - Orbital displacement bearing 2-3 and Figure A10 - Orbital Movement 4, Annex 1. [8]

From the diagnosis of the absolute vibrations of the intermediate bearings 2-3 and the end bearing 4, it is found that the machine qualifies as Good for all measuring regimes, according to Bulletin No. 3. [7]

From the diagnosis of absolute vibrations, the amplitudes of the RMS vibration velocity, these are classified as Admitted under Surveillance for both the $14 \mathrm{MW}$ power regime and the $20 \mathrm{MW}$ regime, according to the Bulletin no. 2. [7] The highest RMS vibration amplitudes were recorded on the bearing 4 in the axial direction.

From the information provided by the beneficiary, it results that the bearing 4 resonates at the speed of $3000 \mathrm{rpm}-50 \mathrm{~Hz}$. For this purpose a series of measurements of the overall vibration level at the bearing 4: $1 \mathrm{x}-50 \mathrm{~Hz}$, as well as the spectral components $2 \mathrm{x}-100 \mathrm{~Hz} / 3 \mathrm{x}-150 \mathrm{~Hz}$, were performed in different variants of dynamic absorbers that were mounted on shaft 4 : from 0 to 8 metal plates mounted in the upper part of the bearing (Figure 7).

From the diagnosis of the absolute vibrations it results that the smallest vibrations were recorded on the bearing 4 on which 5 plates were mounted, obtaining the overall value of $5.57 \mathrm{~mm} \mathrm{/} \mathrm{s,} \mathrm{the}$ component $1 \mathrm{x}$ of $4.59 \mathrm{~mm} / \mathrm{s}$, the $2 \mathrm{x}$ component of Figure 2. Figure A13 - Frequency Spectrum Bearing 4 - Axial / Horizontal / Vertical - Appendix 1. [8]

The maximum measured value RMS $5.57 \mathrm{~mm} / \mathrm{s}$ exceeds the value prescribed by ISO 10816-3: 2009 of $4.5 \mathrm{~mm} / \mathrm{s}$ for the Usable rating and falls under the Admitted under supervision rating. 


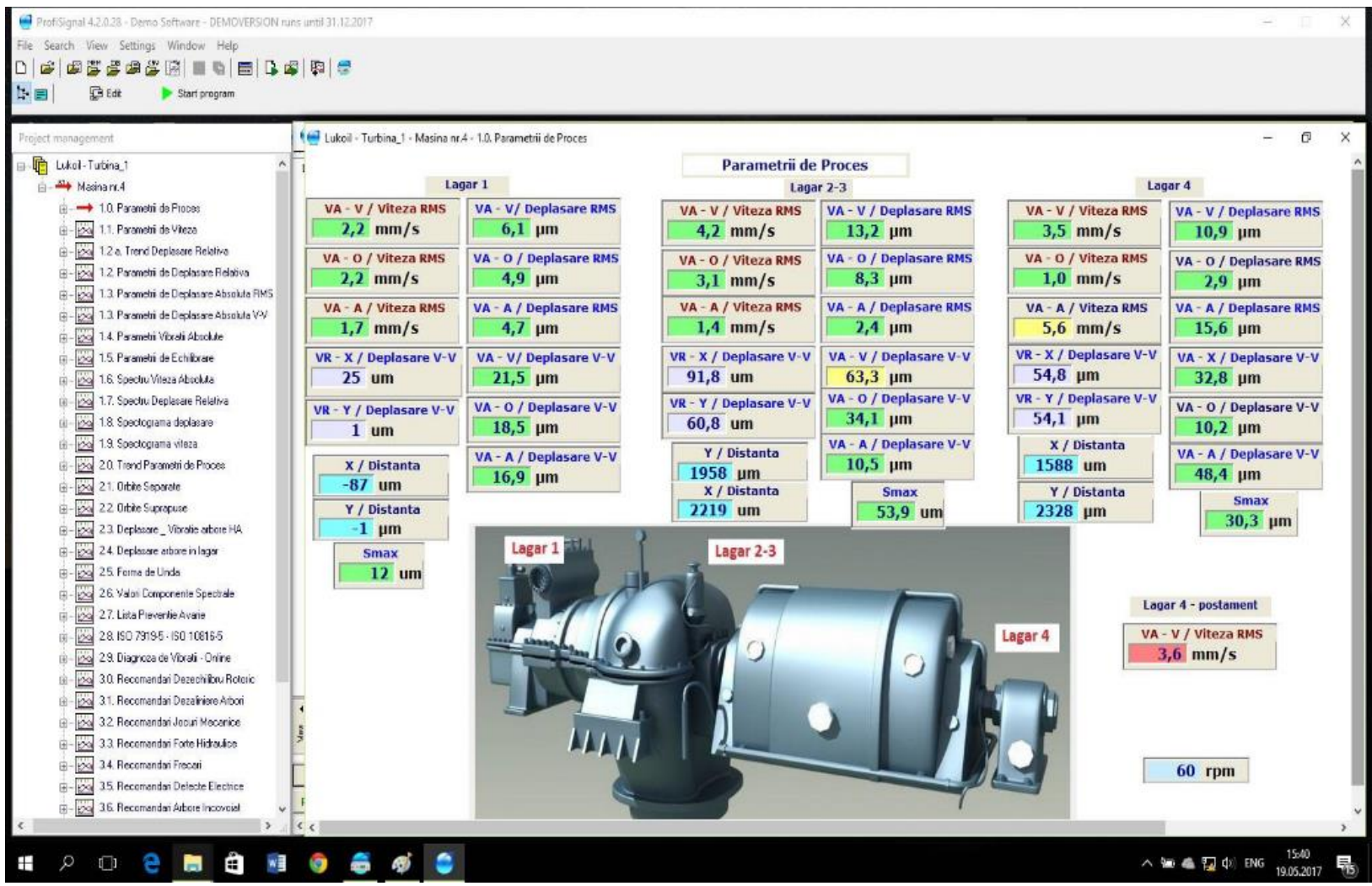

Figure 7: Turbo aggregate Vibration Parameters - Measurement Mode: 5 plates on the bearing 4

\section{Conclusions and Recommendations}

For the correct diagnosis of the machine, it is recommended to carry out additional measurements in other working modes such as:

- raising the rpm from $0 \mathrm{rpm}$ to the nominal speed of $3000 \mathrm{rpm}$ and over $3000 \mathrm{rpm}$ to determine the displacement of the center position of the spindle in the bearing (orbital) and the resonance frequency for the bearing 4 . The relative and absolute global vibration shall be measured, the relative displacement of the spindle, component $1 \mathrm{x}, 2 \mathrm{x}$ simultaneously with phase measurement.

- Nominal idle speed at rated rpm of $3000 \mathrm{rpm}$, at an elevated void and at a maximum load of 20 MW.

- Measuring the transmissibility of three-axial vibrations from the bearing 4 to the base / basis plate - the concrete foundation of the generator casing.

The first two types of measurements were not possible due to the unavailability of the machine. If the increased speed vibration is due to the resonance frequency of the bearing 4 , it can be reduced by mounting masses on the bearing.

\section{References}

[1] Introducereînvibrații － Ref.Doc.MI 119 Notătehnică / Mobil Industrial - Pitești (2013)
[2] Mentenanțautilajelordinamicevol. 1 - Mobil Industrial AG - Pitești (2011)

[3] Vibration Calibration Technique and basics of Vibration Measurement -Torben R. Licht Singapore 2011

[4] An Introduction to Vibration Analysis Theory and Practice

[5] Automated machinery maintenance - Bill Powel , Tony Burnet

[6] Bill Duncan - "Bureau of Reclamation Plumb and Alignment Standards for Vertical Shaft Hydrounits".

[7] S.C. VIBRO SYSTEM S.R.L. www.vibrosystem.ro Buletin de măsurare a nivelului global de vibraţii relative NR. 1; Buletin de măsurare a nivelului global de vibraţii relative NR. 2; Buletin de măsurare a nivelului global de deplasareabsolută NR. 3

[8] S.C. VIBRO SYSTEM S.R.L. www.vibrosystem.ro Raporttehnicprivindmăsurătorile de vibrațiiefectuatecusistemul de diagnoză expert vibro la turboagregatul TA 4 - CET II LUKOIL ENERGY\&GAS S.R.L. mai 2017

[9] ** * ISO 7919-1: 1996- Vibraţii mecanice ale maşinilor. rotativi şiriteriile de evaluare. Partea 1: Prescripţii generale.

[10] ** * ISO 7919-3: 1996 Vibraţiimecanice. Evaluareavibraţiilormașinilorprinmăsurători ale arboreluirotativ. Partea 3: Masiniindustrialecuplate. 
Experimental Results of Turbo-Aggregate Vibroacoustic Diagnosis Obtained with Vibro-Expert System for One Turbo Aggregate in Lukoil Refinery

[11] *** ISO 10816-1 : 1995 Vibraţiimecanice. Evaluareavibraţiilormaşinilorprinmăsurătoripep ărţile non-rotative. Partea 1: Prescripţiigenerale

[12] *** ISO 10816-3 - 2009 Vibraţiimecanice. ărţile non-rotative. Partea 3: Maşiniindustriale cu putereanominalapeste $15 \mathrm{~kW}$ şituraţiaîntre 120 rpm și 15000 rpm măsurate in situ.

Evaluareavibraţiilormaşinilorprinmăsurătoripep

\section{Appendix}

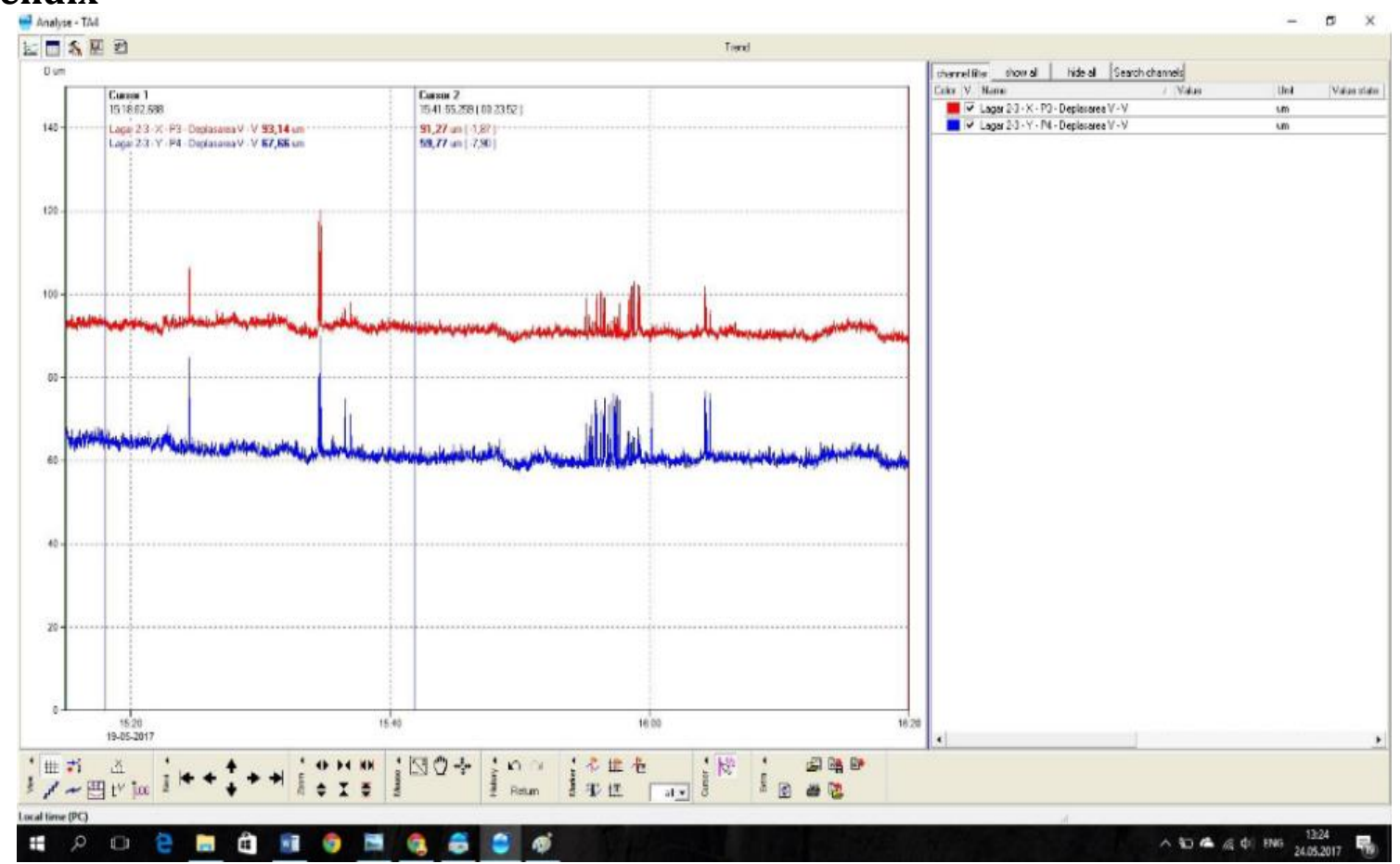

Figure 8: A.1. Trend vibration parameters relative to bearing 2-3. Measuring mode: 8 ... 0 plates on bearing 4, cursor 1 - 8 plates / cursor 2 - 5 plates

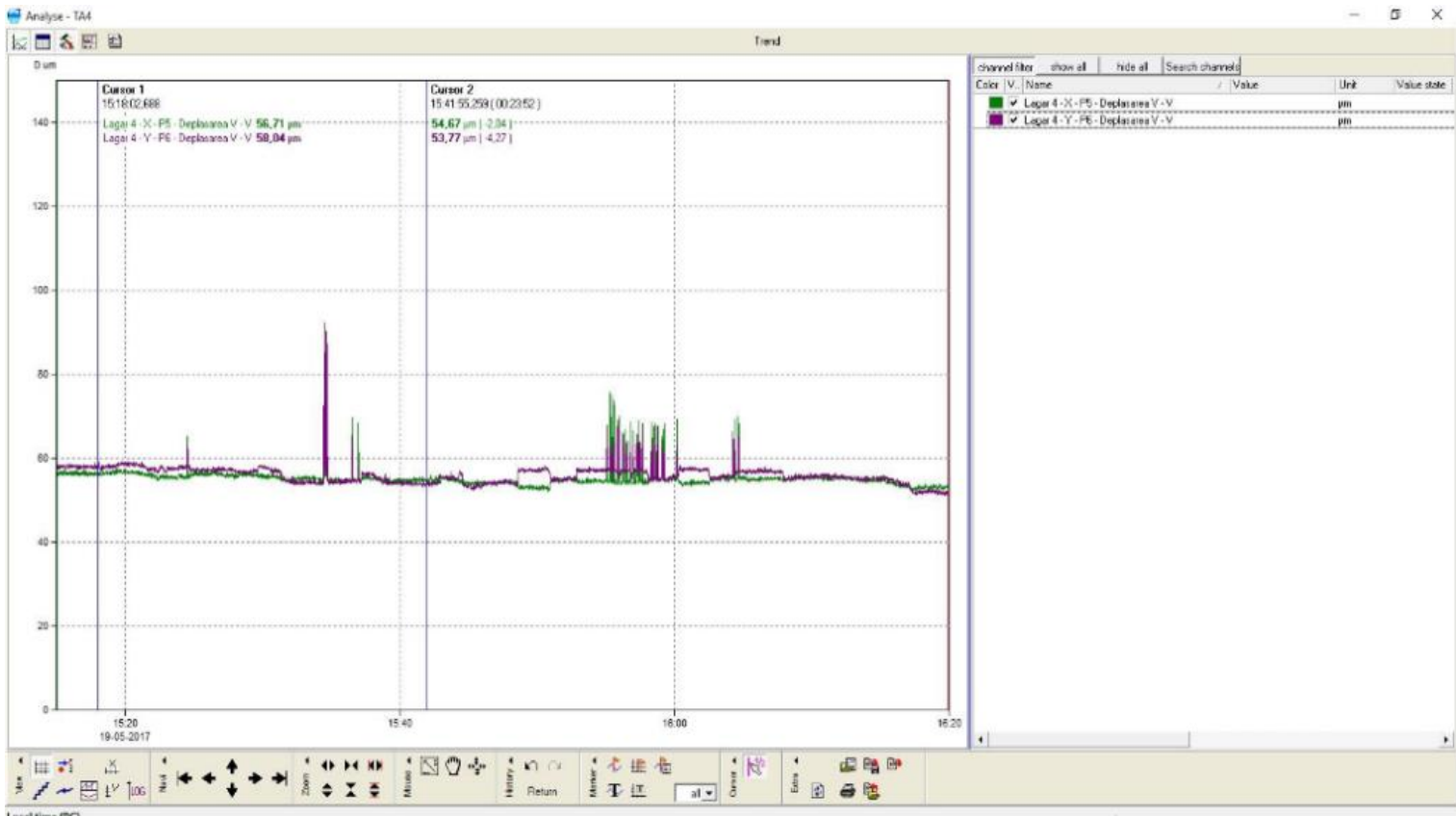

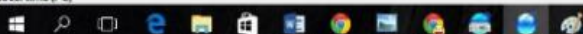

Figure 9: A.2 Trend vibration parameters relative to bearing 4. Measuring mode: 8 ... 0 plates on bearing 4, cursor 1 - 8 plates / cursor 2 - 5 plates 


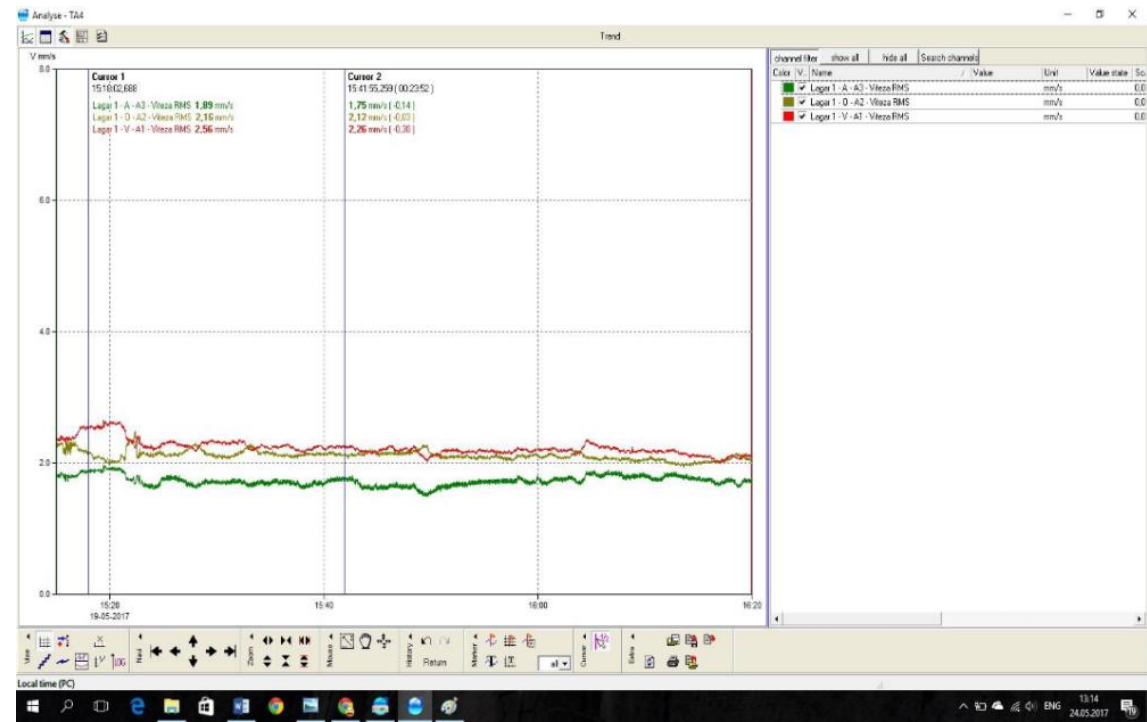

Figure10: A.3 Trend vibration parameters absolute to bearing 1. Measuring mode: 8 ... 0 plates on bearing 4, cursor 1 - 8 plates / cursor 2 - 2 plates

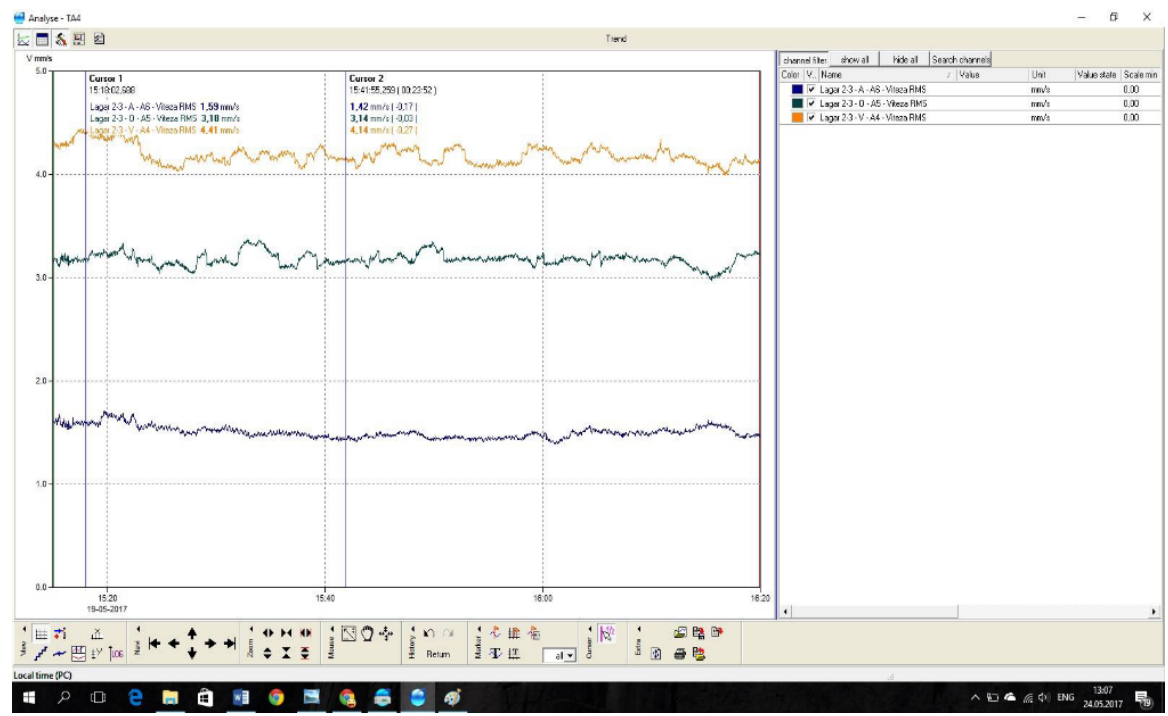

Figure11: A.4 Trend vibration parameters absolute to bearing 2-3. Measuring mode: 8 ... 0 plates on bearing 4, cursor 1 - 8 plates / cursor 2 - 2 plates

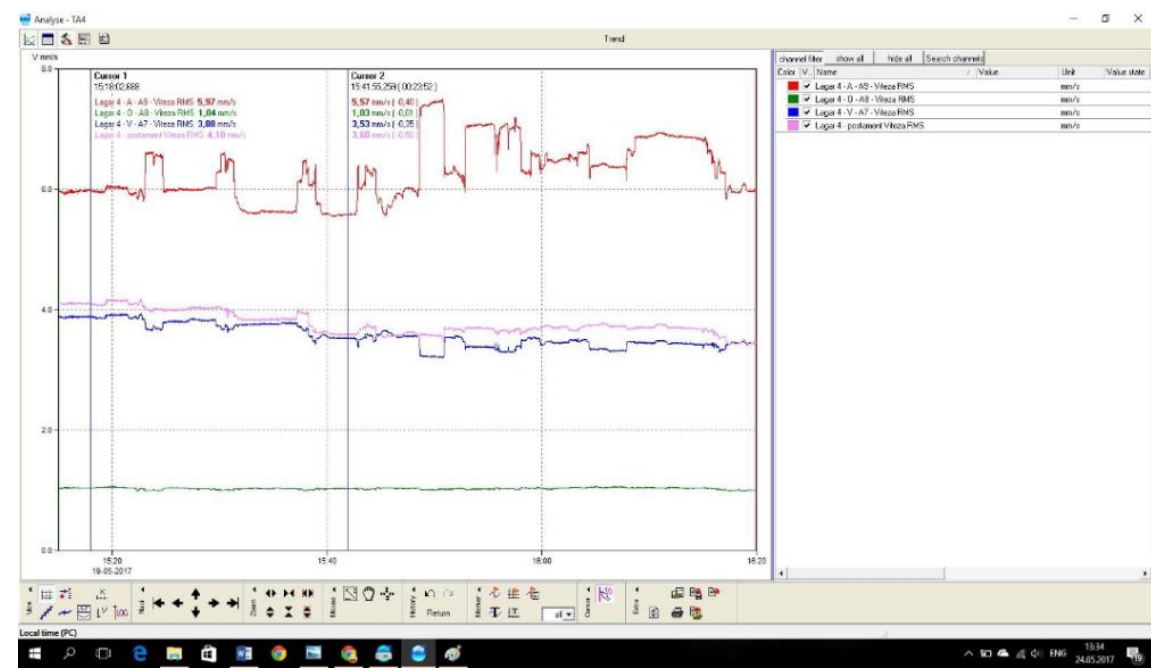

Figure12: A.5. Trend absolute speed bearing 4 and base. Measuring mode: 8 ... 0 Plates on bearing 4, Cursor 1 - 8 Plates / Cursor 2 - Plates 


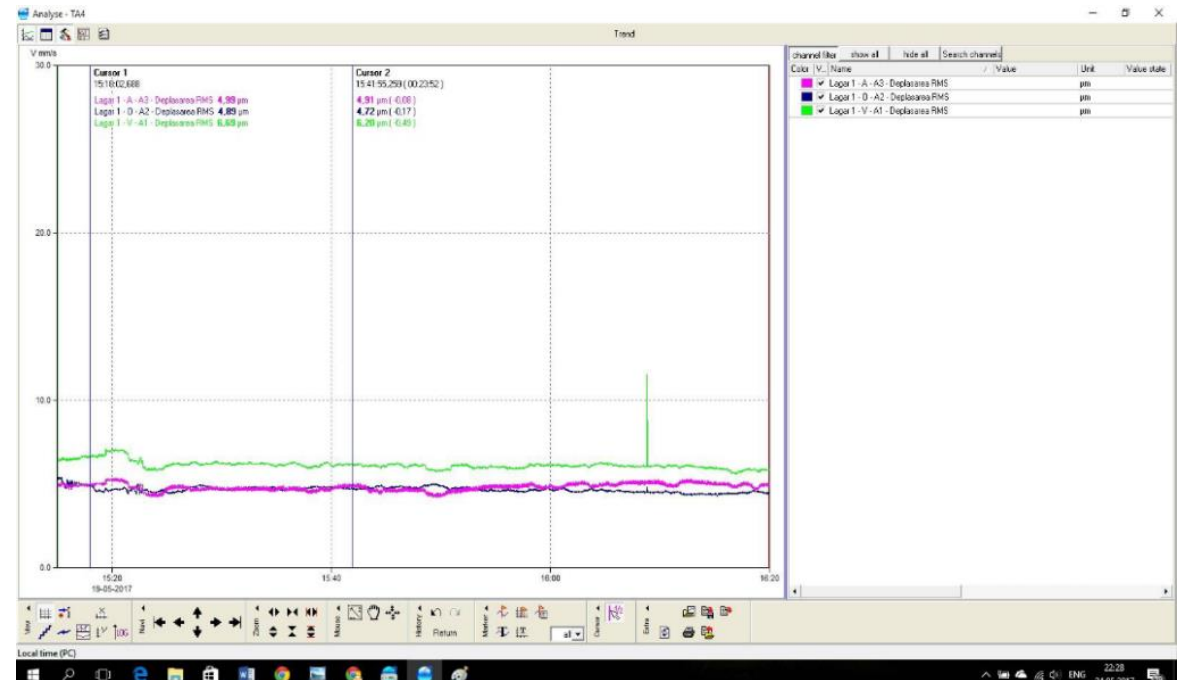

Figure13: A.6. Trend absolute speed bearing 1 and base. Measuring mode: 8 ... 0 Plates on bearing 4, Cursor 1 - 8 Plates / Cursor 2 - Plates

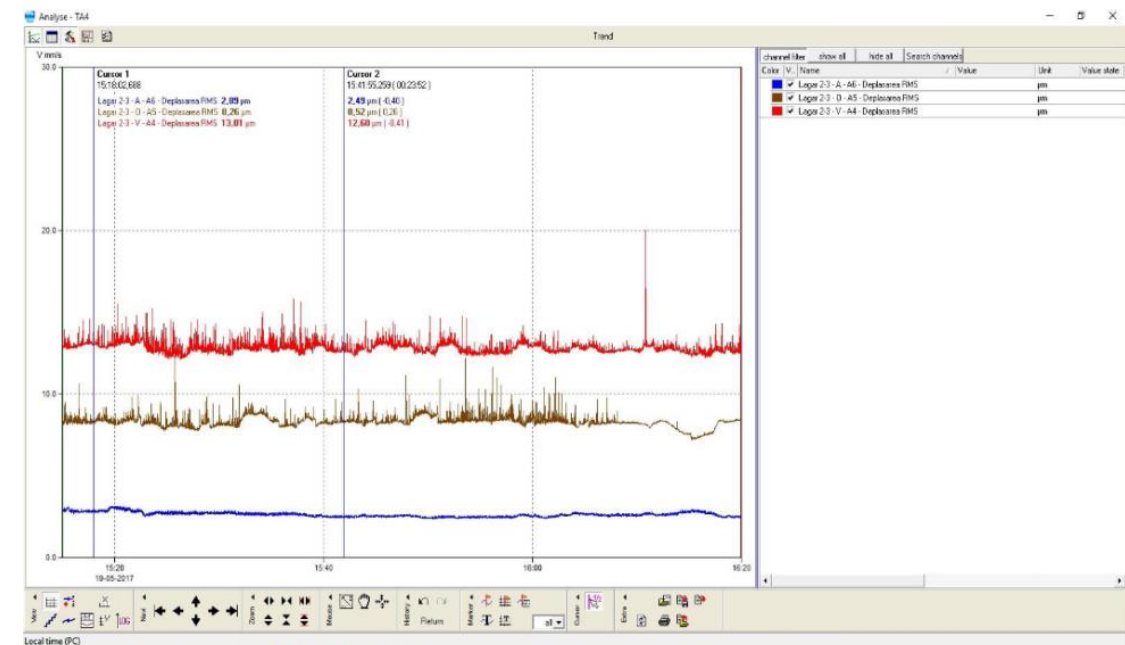

Figure14: A.7. Trend absolute speed bearing 2-3 and base. Measuring mode: 8 ... 0 Plates on bearing 4, Cursor 1 - 8 Plates / Cursor 2 - Plates
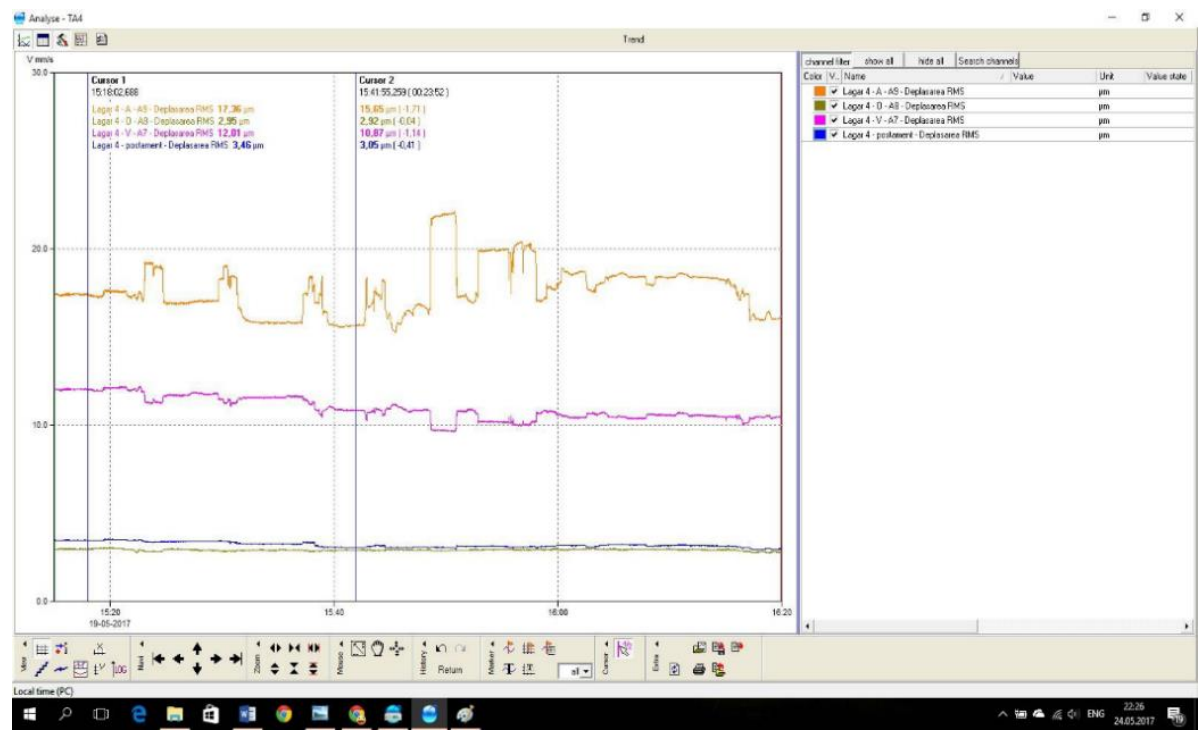

Figure15: A.8. Trend absolute speed bearing 4 and base. Measuring mode: 8 ... 0 Plates on bearing 4, Cursor 1 - 8 Plates / Cursor 2 - Plates 
Experimental Results of Turbo-Aggregate Vibroacoustic Diagnosis Obtained with Vibro-Expert System for One Turbo Aggregate in Lukoil Refinery

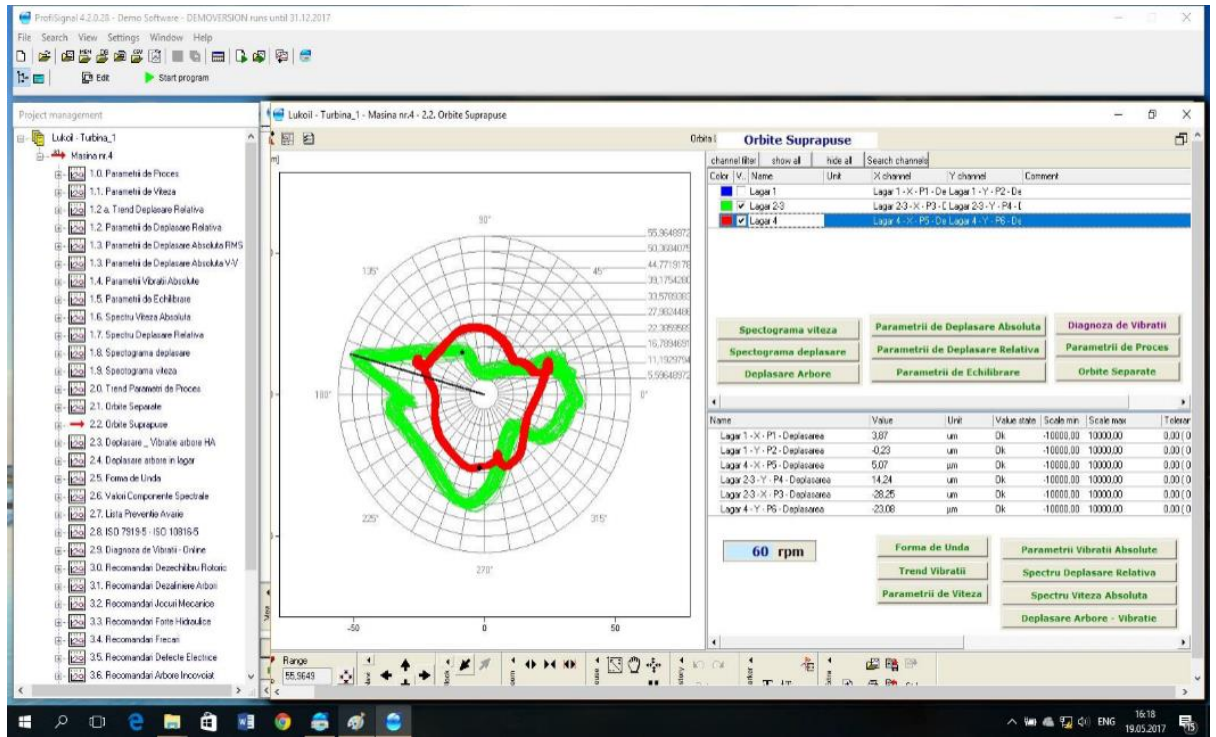

Figure16: A.9.Orbital movement bearing 2-3 and bearing 4. Measuring regime: 5 plates on the camp 4

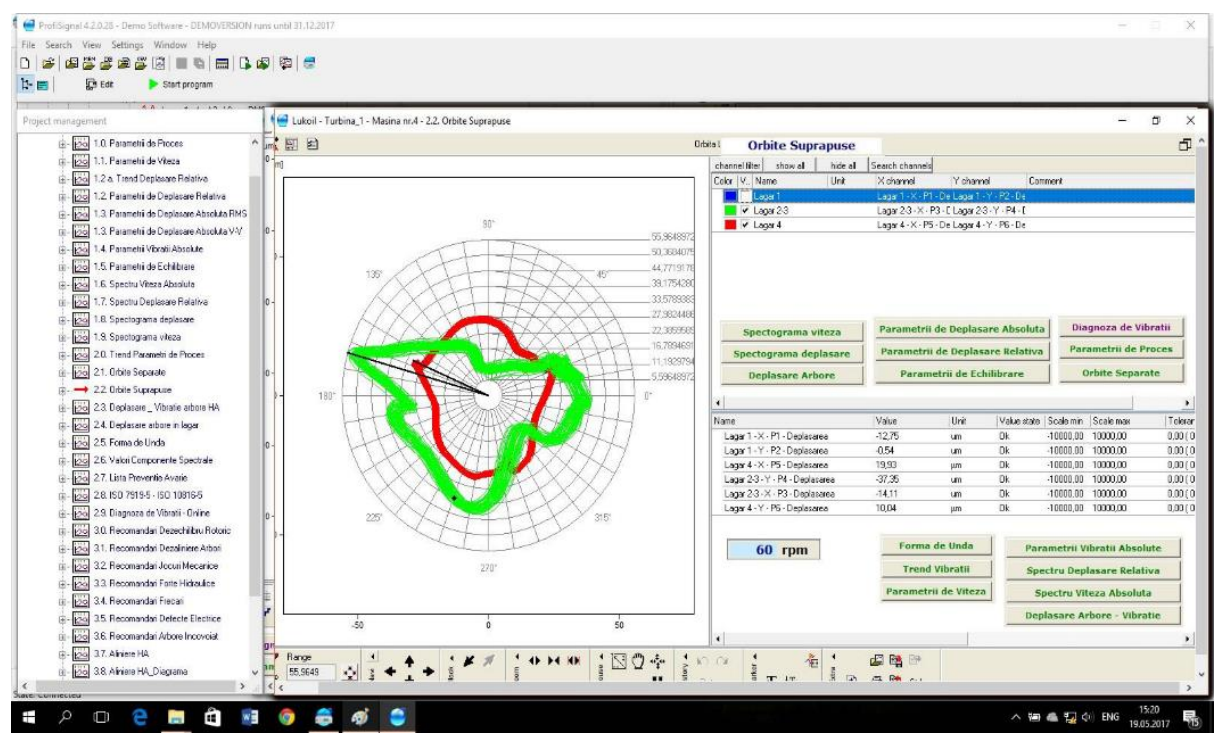

Figure17: A.10.Orbital movement bearing 2-3 and bearing 4. Measuring regime: 8 plates on the camp 4

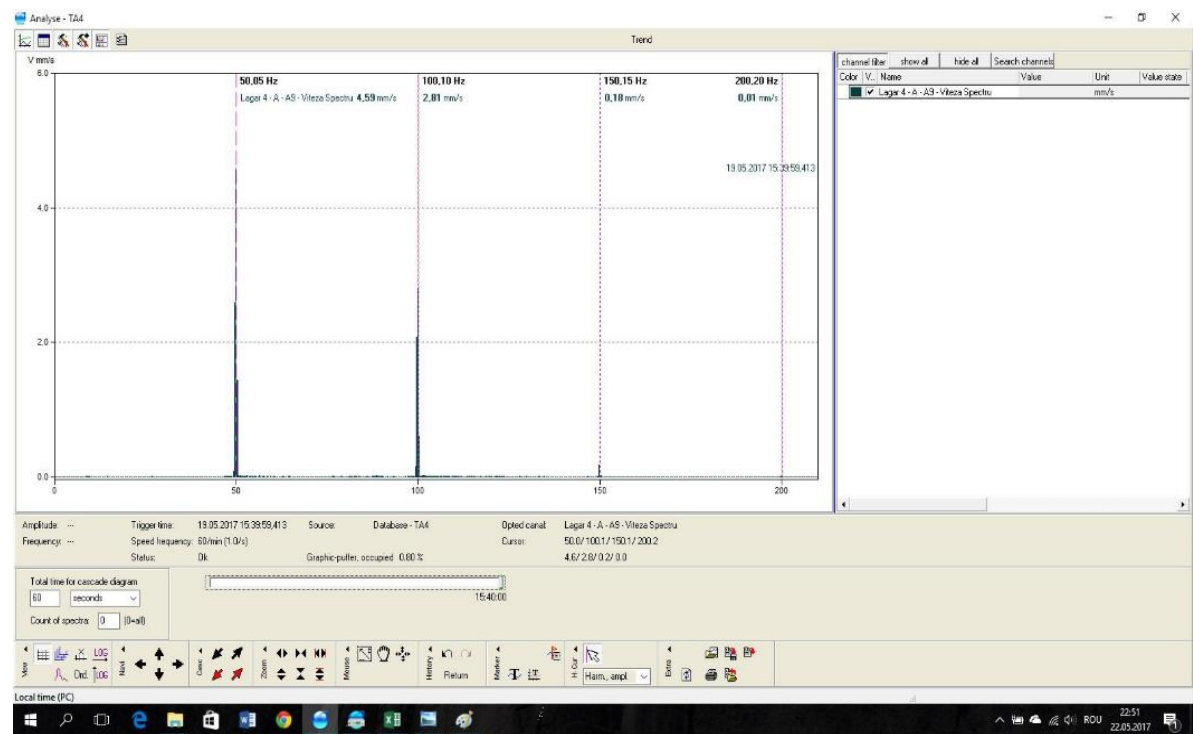

Figure18: A.11. Frequency Spectrum Bearing 4 - Axial - Measuring mode: 5 plates on bearing 4 


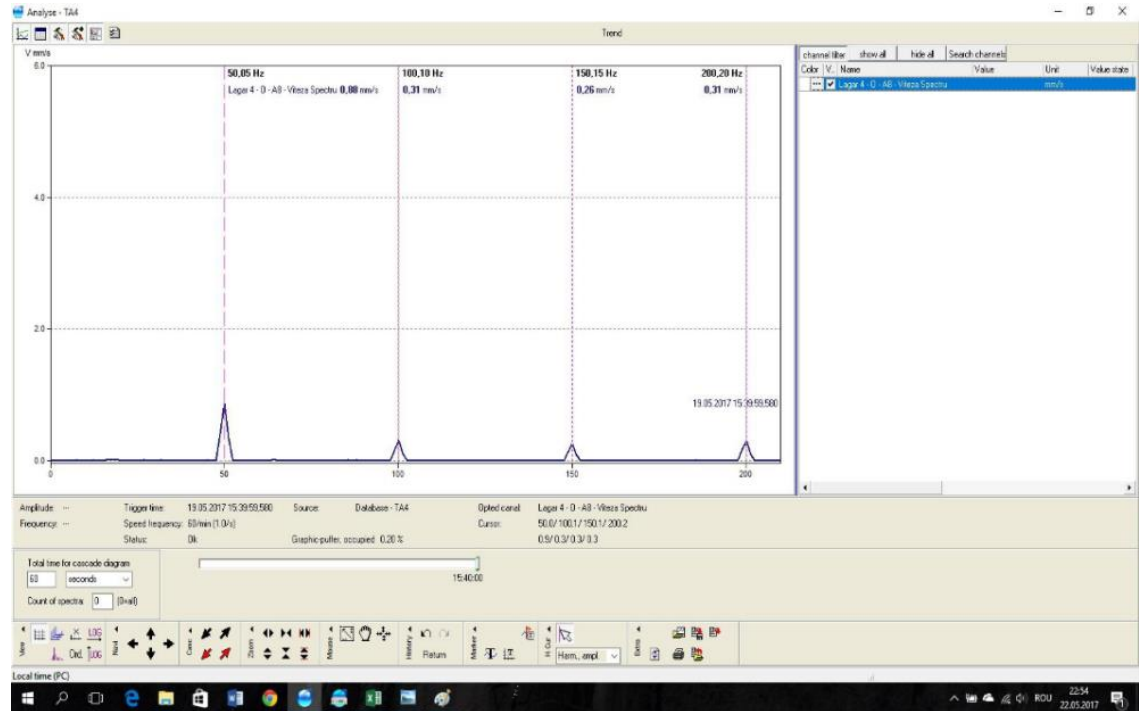

Figure19: A.12. Frequency Spectrum Bearing 4 - Horizontal - Measuring mode: 5 plates on bearing 4

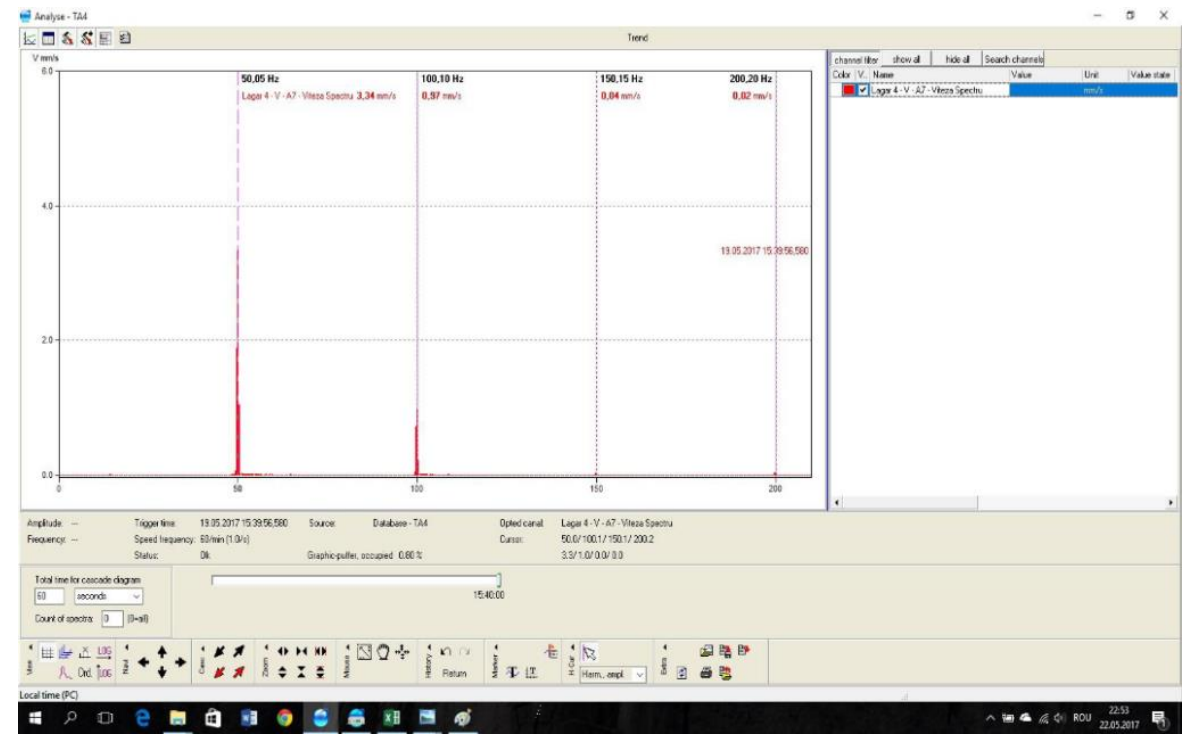

Figure20: A.13. Frequency Spectrum Bearing 4 - Vertical - Measuring mode: 5 plates on bearing 4

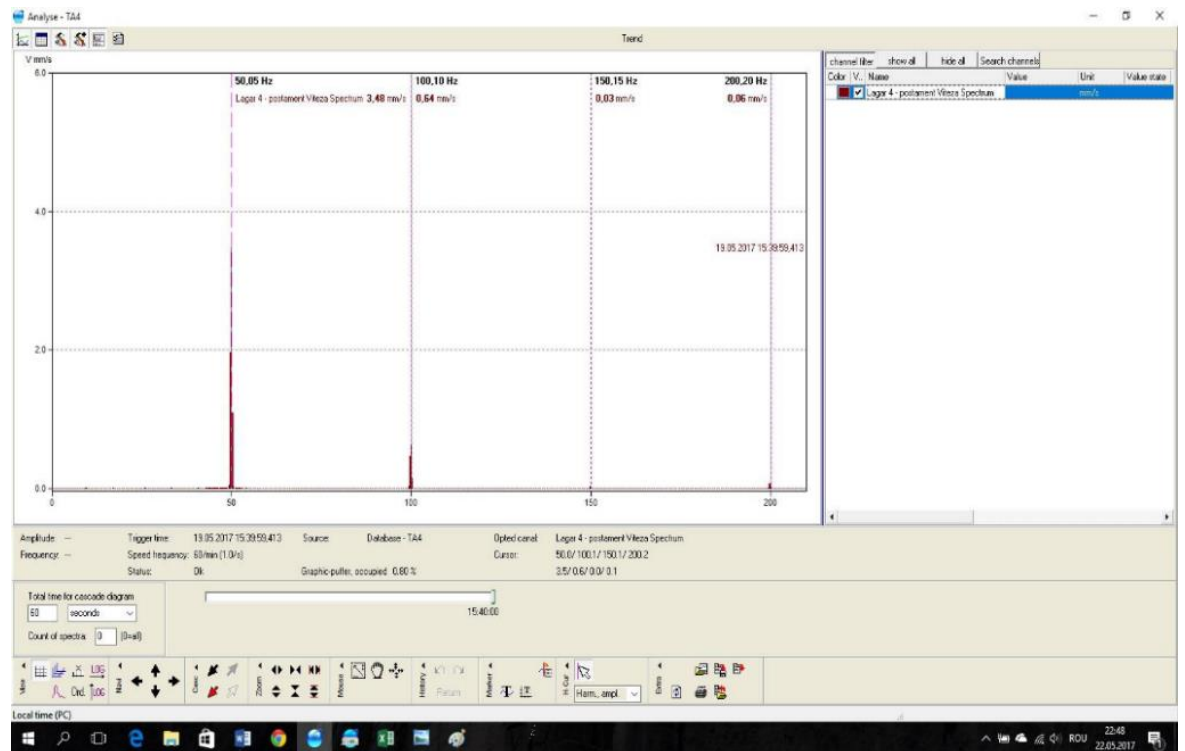

Figure21: A.14. Frequency Spectrum Bearing 4 - Vertical Postament - Measuring mode: 5 plates on bearing 4 